\title{
PEMENUHAN RESTITUSI DAN KOMPENSASI SEBAGAI BENTUK PERLINDUNGAN BAGI KORBAN KEJAHATAN SEKSUAL DALAM SISTEM HUKUM DI INDONESIA
}

\author{
Atikah Rahmi \\ Fakultas Hukum Universitas Muhammadiyah Sumatera Utara \\ Jl. Kapten Mukhtar Basri No. 3, Medan - Sumatera Utara \\ Email: atikahrahmi@umsu.ac.id
}

\begin{abstract}
Abstrak
Kejahatan seksual adalah bentuk kejahatan yang melecehkan dan menodai martabat manusia. Kejahatan-kejahatan ini memiliki dampak luar biasa pada para korban, dalam bentuk fisik, psikologis, ekonomi dan sosial. Dampak yang dialami oleh korban akan benar-benar meningkat dengan reaksi masyarakat ketika perempuan menjadi korban. Kondisi para korban semakin terpojok, mereka menjadi terbatas dalam menjalankan peran sosialnya. Korban mengalami trauma yang berkepanjangan yang membutuhkan pemulihan. Upaya perlindungan hukum terhadap perempuan dan anak-anak korban kejahatan seksual adalah perjuangan untuk hak-hak mereka. Restitusi dan kompensasi adalah bentuk perlindungan sebagai bagian dari hak asasi manusia pada kesejahteraan dan jaminan sosialnya, suatu bentuk perlindungan yang harus dipenuhi bagi para korban kejahatan seksual. Konsep kompensasi bagi korban sejauh ini masih bergantung pada konsep restitusi yang dibebankan langsung kepada para pelaku. Paradigma ini seharusnya diubah, terutama bagi para korban kejahatan seksual, baik anak-anak maupun orang dewasa. Korban kejahatan seksual seharusnya tidak lagi bergantung pada kewajiban para pelaku, tetapi juga kepada negara yang berkewajiban memberikan kompensasi kepada para korban.
\end{abstract}

\section{Kata Kunci: Restitusi dan kompensasi, perlindungan, korban}

\section{Abstract}

Sexual crime is a form of crime that harasses and tarnishes human dignity. These crimes have a tremendous impact on victims, in the form of physical, psychological, economic and social. The impact experienced by victims will actually increase with the reaction of the community when women become victims. The condition of the victims was increasingly cornered, they became limited in carrying out their social roles. Victims experience prolonged trauma that requires recovery. Legal protection efforts against women and children victims of sexual crimes are a struggle for their rights. Restitution and compensation are forms of protection as an integral part of human rights in the field of welfare and social security, a form of protection that must be met for victims of sexual crimes. The concept of compensation for victims so far still relies on the concept of restitution charged directly to the perpetrators. This paradigm should have been changed, especially for victims of sexual crimes, both child and adult. Victims of sexual crime should no longer rely on the obligations of the perpetrators, but also the responsibility of the State by providing compensation to victims.

Keywords: Restitutions, Compentation, Victim

\section{PENDAHULUAN}

Kejahatan seksual terhadap perempuan adalah pelanggaran Hak Asasi Manusia (HAM). 
Jurnal Ilmu Hukum FAKULTAS HUKUM UMSU
Pemenuhan Restitusi Dan...(Atikah Rahmi)

Volume 4 Nomor 2, Juli-Desember 2019, 140-159 DOI: https://doi.org/10.30596/dll.v4i2.3173

Kejahatan seksual merupakan bentuk kejahatan yang melecehkan dan menodai harkat kemanusiaan, serta dapat dikategorikan sebagai jenis kejahatan luar biasa (extra ordinary crime) (Atikah Rahmi, 2018, h. 58). Kejahatan seksual terhadap perempuan merupakan pelanggaran hak-hak konstitusi warga Negara sebagaimana dicantumkan dalam UndangUndang Dasar Republik Indonesia Tahun 1945 (UUD RI 1945). Pelanggaran hak-hak dimaksudkan, khususnya hak atas perlindungan diri dan hak atas rasa aman, dalam Pasal 28G ayat 1hak untuk hidup sejahtera lahir dan batin serta mendapat lingkungan hidup yang baik dan sehat (Pasal 28H ayat 1) serta hak untuk bebas dari perlakuan yang diskriminatif atas dasar apapun dan hak atas perlindungan terhadap perlakuan yang bersifat diskriminatif (Pasal 28 I ayat 2), hak untuk mendapat kemudahan dan perlakuan khusus untuk memperoleh kesempatan dan manfaat yang sama guna mencapai persamaan dan keadilan (Pasal 28 ayat 2), serta hak atas pengakuan, jaminan, perlindungan, dan kepastian hukum yang adil serta perlakuan yang sama di hadapan hukum (Pasal 27 ayat 1 dan Pasal 28 D ayat 1).

Pelanggaran terhadap Hak Asasi Manusia seseorang sering terjadi dalam kehidupan nyata, baik yang dilakukan oleh individu, kelompok, maupun negara. Pelanggaran HAM tersebut mengakibatkan munculnya ketidakseimbangan dalam diri seseorang (korban) dan maupun keluarganya, seperti ketidakseimbangan dari aspek finansial, jika korban merupakan kepala keluarga dan tumpuan hidup keluarga. Aspek fisik yang mengakibatkan korban berhenti beraktivitas, aspek psikis, yang berwujud munculnya kegoncangan atau ketidakstabilan psikis baik secara temporer maupun permanen dari korban. Untuk menyeimbangkan kondisi korban (keluarga), sehingga dapat pulih kembali pada keadaan semula, maka harus ditempuh berbagai upaya pemulihan, seperti pemulihan secara finansial, medis, dan psikis (mental) korban. (Mansur, Dikdik M.Arief, dkk, 2007, h. 160-161).

Abu Hamzah 'Abdul Lathif al Ghamidi mengemukakan bahwa kekerasan merupakan sebuah kata mengerikan yang benar-benar bisa mengguncang hati dan jiwa, sebuah kata yang bisa mengubah kedamaian menjadi kericuhan, senyuman menjadi tangisan, ketenanangan menjadi kekacauan dan kebahagiaan menjadi penderitaan. Pada hakikatnya, kekerasan merupakan pemusnahan kasih sayang, pembunuhan nurani, pengganyangan perasaan, penikaman hati dan penusukan jantung. Kekerasan inilah yang membuat kehidupan menjadi kacau, kepahitan yang akibatnya memperburuk kehidupan dan eksistensinya membuat makhluk teraniaya (Abu Hamzah 'Abdul Lathif al Ghamidi, 2010, h. 17).

Pasal 27 ayat (1) UUD RI 1945 menjelaskan bahwa "segala warga Negara bersamaan kedudukannya di dalam hukum dan pemerintahan dan wajib menjunjung tinggi hukum dan pemerintahan itu dengan tidak ada kesualiannya". Pasal di atas menunjukkan bahwa negara berkomitmen untuk perlakuan baik dan adil terhadap warga negaranya, termasuk apakah seorang warga itu sebagai tersangka ataupun korban tindak pidana.

Setiap warga negara berhak memperoleh rasa aman dan bebas dari segala bentuk kekerasan sesuai dengan ideologi dan konstitusi bangsa Indonesia. Segala bentuk kekerasan, terutama kekerasan dalam rumah tangga, merupakan pelanggaran hak dasar manusia dan kejahatan terhadap martabat kemanusiaan serta bentuk diskriminasi yang harus dihapus. 
Jurnal Ilmu Hukum FAKULTAS HUKUM UMSU
Pemenuhan Restitusi Dan...(Atikah Rahmi)

Volume 4 Nomor 2, Juli-Desember 2019, 140-159 DOI: https://doi.org/10.30596/dll.v4i2.3173

(Muhammad Taufik Makarao, dkk, 2013, h. 2). Oleh sebab itu, korban kekerasan yang umumnya adalah perempuan harus mendapatkan perlindungan dari negara dan masyarakat agar terhindar dari kekerasan atau ancaman kekerasan, penyiksaan atau perlakuan yang merendahkan derajat dan martabat kemanusiaan.

Berkaitan dengan perlindungan terhadap korban kejahatan, ada upaya preventif dan represif yang dapat dilakukan, baik oleh masyarakat maupun pemerintah (melalui aparat penegak hukumnya), seperti pemberian perlindungan atau pengawasan dari berbagai ancaman yang dapat membahayakan nyawa korban, pemberian bantuan medis, maupun hukum secara memadai (La Jamaa, 2014, h. 252). Negara pada prinsipnya menjamin akses keadilan bagi semua masyarakat tanpa membedakan laki-laki dan perempuan, hal ini tercermin melalui Pasal 28D ayat 1 UUD RI Tahun 1945 yang berbunyi "Setiap orang berhak atas pengakuan, jaminan, perlindungan dan kepastian hukum yang adil serta perlakuan yang sama di hadapan hukum". Negara melalui konstitusi dan prinsip-prinsip HAM menjamin terpenuhinya hak-hak warga negara, termasuk hak dari perempuan korban kekerasan, baik perempuan dewasa maupun anakanak.

Perlindungan hukum terhadap perempuan sebagai korban kekerasan harus lebih ditingkatkan, mengingat tingginya angka kasus kekerasan terhadap perempuan, baik kekerasan dalam rumah tangga dan maupun kekerasan seksual terhadap anak perempuan. Kekerasan terhadap perempuan menjadi konsekuensi paling serius dari ketidaksetaraan gender. Perempuan kerapkali mengalami kekerasan berlapis, baik fisik maupun mental, di rumah maupun dalam masyarakat. Faulkher mengemukakan data bahwa 31\% narapidana perempuan di Amerika Serikat merupakan korban kekerasan seksual di masa kecil. 95\% pekerja seksual merupakan korban seksual anak. $40 \%$ penyerang seksual anak dan $76 \%$ pemerkosa berantai mengalami kekerasan seksual di masa anak-anak (Faulkher dalam Zahra, 2007).

Berdasarkan catatan akhir tahun Komnas Perempuan tahun 2016, terdapat 259.150 kasus kekerasan terhadap perempuan yang terdiri atas 245.548 kasus bersumber pada data dari perkara yang ditangani oleh 359 Pengadilan Agama di Indonesia dan 13.602 kasus yang didampingi oleh lembaga mitra pengada layanan yang tersebar di 34 provinsi. Jenis kekerasan yang berada di tingkat tertinggi adalah kekerasan di ranah personal. Keterangan dari Pengadilan Agama disebutkan bahwa 245.548 kasus kekerasan terhadap isteri yang berakhir dengan perceraian. Sedangkan kasus yang didampingi oleh lembaga pengada layanan tercatat sebanyak 10.205 kasus yang terjadi di ranah personal. Sebanyak 5.784 kasus ranah rumah tangga adalah merupakan kasus kekerasan terhadap isteri, sedangkan selebihnya (2.171 kasus) merupakan kekerasan dalam pacaran dan kekerasan terhadap anak sebanyak 1.799 kasus, sisanya merupakan kekerasan mantan suami dan kekerasan mantan pacar serta kekerasan terhadap pekerja rumah tangga.

Tindakan kekerasan merupakan wujud penindasan dan pelanggaran hak asasi yang dilakukan seseorang kepada orang lain, kelompok tertentu kepada kelompok lain, orang dewasa kepada anak-anak, majikan kepada pembantunya dan laki-laki kepada perempuan. Tindakan ini 
Jurnal Ilmu Hukum FAKULTAS HUKUM UMSU
Pemenuhan Restitusi Dan...(Atikah Rahmi)

Volume 4 Nomor 2, Juli-Desember 2019, 140-159 DOI: https://doi.org/10.30596/dll.v4i2.3173

mencerminkan pihak yang labih kuat cenderung superior dan menempatkan pihak yang lemah sebagai korbannya (Abdul Wahid, Muhammadi Irfan, 2001, h. 54).

Ketidakberpihakan masyarakat terhadap korban semakin melemahkan kondisi mereka, masyarakat sering menyalahkan korban yang haknya sudah direnggut. Seharusnya masyarakat menunjukkan keberpihakannya berupa empati kepada korban dan bukan malah menyudutkan korban dan melakukan reviktimisasi. Penampilan korban dan cara berpakaiannya selalu dijadikan alasan pembenar oleh pelaku untuk melakukan kejahatan seksual terhadap perempuan. Perkosaan terjadi bukan karena pakaian atau penampilan, melainkan kesempatan dan kerentanan. Kerentanan termasuk situasi mental, fokus, waspada dan sadar situasi. Seorang perempuan yang mengenakan pakaian yang sopan, bukan berarti dapat menghindari perkosaan, karena dari hasil penelitian diketahui bahwa penampilan bukan sebab perkosaan.

Upaya untuk menghentikan kejahatan kekerasan seksual merupakan hal penting, karena kekerasan telah menimbulkan berbagai luka pada pihak korban. Dampak dari luka tersebut mengakibatkan korban sulit untuk mengungkapkan kembali kekerasan yang pernah dialaminya. Perlakuan salah dan ketidakadilan yang diderita perempuan tidak mungkin diperbaiki dengan hanya melakukan peradilan pidana terhadap pelaku. Pendekatan yang komprehensif dan koreksi merupakan syarat yang mampu menjamin hak-hak perempuan di semua fase dalam masyarakat. Dalam kenyataannya sistem peradilan pidana dapat dimobilisasi untuk menjadi alat yang lebih efektif dalam menindak, mencegah dan merespons perbuatan kekerasan terhadap perempuan.

Negara bertangungjawab untuk melindungi korban kejahatan seksual dan memberikan pemulihan, serta memastikan hak-hak mereka. Perlu adanya peraturan yang mewajibkan pelaku untuk memberikan restitusi dan kompensasi kepada korban dalam rangka memulihkan hak-hak korban secara total (Atikah Rahmi, 2017, h. 5). Dalam penyelesaian perkara pidana, hukum terlalu mengedepankan hak-hak tersangka/terdakwa, sementara hak-hak korban diabaikan, sebagaimana dikemukakan dalam buku Andi Hamzah; "dalam membahas hukum acara pidana khususnya yang berkaitan dengan hak-hak asasi manusia, ada kecenderungan untuk mengupas hal-hal yang berkaitan dengan hak-hak tersangka tanpa memperhatikan pula hak-hak para korban" (Andi Hamzah, 1986, h. 33).

Hukuman bagi pelaku kejahatan seksual tersebut tentunya masih menyisakan masalah hak-hak keperdataan korban yang telah mengalami kerugian materiil dan imateriil, rohani dan jasmani meliputi kerugian spiritual, mental, jiwa, psikis, fisik, sosial, ekonomi, dan masa depan yang tidak ternilai. Para korban perkosaan terdiri dari (i) pribadi korban perkosaan; (ii) anak hasil perkosaan; (iii) keluarga korban jika korban mati karena perkosaan; dan (iv) masyarakat. Hak-hak keperdataan para korban perkosaan, khususnya pribadi korban dan/atau ahli warisnya sudah jelas dilindungi oleh UUD RI 1945. Berdasarkan ketentuan tersebut, selayaknya para korban diberikan perlindungan hukum secara keperdataan oleh pelaku dan Negara berupa restitusi dan konpensasi (Melalui, https:// media indonesia .com /read /detail /44875rehabilitasi-bagi-korban-kejahatan-seksual).

Marlina dan Azmiati Zuliah menjelaskan bahwa dalam Kitab Undang-Undang Hukum 
Jurnal Ilmu Hukum FAKULTAS HUKUM UMSU
Pemenuhan Restitusi Dan...(Atikah Rahmi)

Volume 4 Nomor 2, Juli-Desember 2019, 140-159

DOI: https://doi.org/10.30596/dll.v4i2.3173

Pidana (KUHP) lebih banyak diatur mengenai tersangka daripada mengenai korban. Kedudukan korban dalam KUHP tampaknya belum optimal dibandingkan dengan kedudukan pelaku (Marlina, Azmiati Zuliah, 2015, h. 61). Menurut Sudarto dalam praktik penerapan hukum pidana, korban diposisikan sebagai saksi korban dan terkadang mengabaikan posisi korban sebagai pencari keadilan. Dalam proses persidangan, korban diwakilkan kepada penegak hukum (Sudarto, 1986, h. 184). Reaksi terhadap pelaku delik menjadi hak penuh Negara untuk diselesaikan. Sehubungan dengan pernyataan Sudarto dan Maya Indah yang menekankan bahwa perlindungan korban khususnya hak untuk memperoleh ganti rugi merupakan bagian integral dari hak asasi di bidang kesejahteraan dan jaminan sosial (social security) (Sudarto, Maya Indah, 2014, h. 133).

Restitusi dan kompensasi yang pada prinsipnya sudah diatur dalam beberapa perundang-undangan seperti; Undang-Undang Nomor 26 Tahun 2000 tentang Pengadilan Hak Asasi Manusia, Perubahan atas Undang-Undang Nomor 15 Tahun 2003 tentang Penetapan Peraturan Pemerintah Pengganti Undang Undang-Nomor 1 Tahun 2002 tentang Pemberantasan Tindak Pidana Terorisme Menjadi Undang-Undang, Undang-Undang Momor 13 Tahun 2006 tentang Perlindungan Saksi dan Korban, Undang-Undang Nomor 21 Tahun 2007 tentang Perdagangan Orang, namun pelaksanaannya belum berjalan efektif. Pengajuan restitusi sebenarnya dapat dilakukan mulai dari proses penyelidikan di kepolisian, hingga ke tingkat peradilan, namun masih banyak aparat penegak hukum yang tidak melakukannya. Sementara itu, korban dan keluarganya juga tidak mendapatkan informasi mengenai hal itu. Pelaksanaan pemenuhan hak restitusi bagi korban masih mengalami banyak hambatan, untuk itu perlu ada pembahasan mengenai model pemenuhan ganti kerugian yang dapat secara langsung dirasakan manfaatnya oleh korban dan keluarganya.

Pada konteks melihat pemenuhan restitusi dan kompensasi sebagai bentuk perlindungan bagi korban kejahatan seksual dalam sistem hukum di indonesia. sehingga yang menjadi fokus permasalahan dalam penulisan ini adalah bagaimana pemenuhan restitusi dan kompensasi sebagai bentuk perlindungan bagi korban kejahatan seksual dalam sistem hukum di indonesia dengan harapan tulisan ini dapat bermanfaat baik secara teori maupun praktis bagi khalayak luas dalam rangka melihat pemenuhan restitusi dan kompensasi sebagai bentuk perlindungan bagi korban kejahatan seksual dalam sistem hukum di indonesia.

\section{METODE PENELITIAN}

Penulisan ini menggunakan metode penelitian hukum yuridis normatif (normatif research), yaitu penelitian hukum yang dilakukan dengan cara meneliti bahan pustaka atau data skunder (Seokanto dan Sri Muji, 2003, h. 15). Spesifikasi penelitian dalam penulisan ini berupa penelitian deskriptif analistis. Deskriptif adalah menunjukan komparasi atau hubungan seperangkat data dengan seperangkat data yang lain, dan maksudnya adalah untuk memberikan gambaran, menelaah, menjelaskan dan menganalisis (Soekanto, 1996, h. 63).

Sesuai jenis dan sifat penelitiannya, maka sumber data yang digunakan dalam penulisan ini adalah data skunder yang terdiri dari bahan hukum primer undang-undang yang berkaitan 
Jurnal Ilmu Hukum

FAKULTAS HUKUM UMSU

dengan pemenuhan restitusi dan kompensasi sebagai bentuk perlindungan bagi korban kejahatan seksual dalam sistem hukum di indonesia. Bahan hukum sekunder terdiri dari bukubuku, jurnal ilmiah, makalah dan artikel ilmiah yang dapat memberi penjelasan tentang bahan hukum primer. Bahan hukum tersier; berupa Kamus Besar Bahasa Indonesia (KBBI) dan lain sebagainya dalam menemukan defenisi dari istilah-istilah dalam membahas tentang pemenuhan restitusi dan kompensasi sebagai bentuk perlindungan bagi korban kejahatan seksual dalam sistem hukum di indonesia.

Prosedur yang digunakan untuk mengumpulkan data dalam penilitian ini berupa dokumentasi yaitu pedoman yang digunakan berupa catatan atau kutipan, penelusuran literatur hukum, buku-buku dan lainnya yang bertalian dengan identifikasi masalah dalam penilitian ini yaitu mengenai syarat subjektifitas dan objektifitas penangguhan penahanan sesuai yang diatur di dalam Kitab Undang-Undang Hukum Acara Pidana (KUHAP). Analisa bahan hukum dilakukan dengan menggunakan metode analisa konten (centent analysis method) yang dilakukan dengan menguraikan materi peristiwa hukum atau produk hukum secara rinci guna memudahkan interpretasi dalam pembahasan (Marzuki, 2011, h. 171).

\section{PEMBAHASAN}

\section{Pemenuhan Restitusi Dan Kompensasi Sebagai Bentuk Perlindungan Bagi Korban Kejahatan Seksual Dalam Sistem Hukum di Indonesia}

\section{Realitas kekerasan seksual}

Kekerasan terhadap perempuan dapat didefinisikan secara sederhana sebagai segala bentuk perilaku yang dilakukan kepada perempuan yang memunculkan akibat psikis berupa perasaan takut hingga akibat berupa perlukaan fisik. definisi ini sedemikian luasnya sehingga meliputi mulai dari pelecehan seksual berupa siulan atau godaan terhadap perempuan, hingga pembiaran oleh Negara pada kondisi perempuan warga negaranya yang menjadi korban kekerasan (Niken Savitri, 2008, h. 47).

Kekerasan seksual adalah sebagai suatu perbuatan yang mencakup pelecehan seksual sampai kepada memaksa seseorang untuk melakukan hubungan seksual tanpa persetujuan korban atau disaat korban menghendaki dan atau tidak disukai korban dan atau menjauhkan (mengisolasi) demi kebutuhan seksualnya.

Pasal 1 Deklarasi Penghapusan Kekerasan Terhadap Perempuan disebutkan bahwa yang dimaksud dengan kekerasan terhadap perempuan adalah setiap perbuatan berdasarkan perbedaan jenis kelamin yang berakibat atau mungkin berakibat kesengsaraan atau penderitaan perempuan secara fisik, seksual atau psikologis, termasuk ancaman perbuatan tertentu, pemaksaan atau perampokan kemerdekaan secara sewenang-wenang, baik yang terjadi di depan umum maupun dalam kehidupan pribadi.

Kekerasan terhadap perempuan, dikategorikan sebagai kekerasan berbasis gender. Menurut Niken, hal ini disebabkan kekerasan terhadap perempuan seringkali diakibatkan adanya ketimpangan gender karena adanya relasi kekuasaan yang tidak seimbang. Lebih lanjut dijelaskan bahwa akar permasalahan kekerasan yang dilakukan terhadap perempuan 
Jurnal Ilmu Hukum

FAKULTAS HUKUM UMSU
Pemenuhan Restitusi Dan...(Atikah Rahmi)

Volume 4 Nomor 2, Juli-Desember 2019, 140-159

DOI: https://doi.org/10.30596/dll.v4i2.3173

disebabkan adanya relasi gender antara pelaku yang mengendalikan dan korban sebagai orang yang dikendalikan melalui tindakan kekerasan tersebut (Niken 2008, h. 49-50). Kekerasan seksual merupakan istilah yang menunjuk pada perilaku seksual diviatif atau hubungan seksual yang menyimpang, merugikan pihak korban dan merusak kedamaian di tengah masyarakat. Kejahatan kekerasan seksual berakibat pada penderitaan korban yang membutuhkan perhatian serius (Abdul Wahid, Muhammadi Irfan, 2001, h. 32).

Rancangan Undang-Undang tentang Penghapusan Kekerasan Seksual disebutkan pengertian kekerasan seksual, yaitu;

Setiap perbuatan melanggar martabat kemanusiaan seseorang berdasarkan diskriminasi gender yang menyasar pada tubuh dan seksualitas seseorang, yang berakibat atau dapat berakibat kerugian atau penderitaan fisik, psikis, ekonomi, seksual, politik dan atau sosial korban.

Kekerasan seksual yang dialami perempuan merupakan bentuk kerendahan posisi perempuan terhadap kepentingan seksual laki-laki. Citra seksual perempuan yang telah menempatkan dirinya sebagai objek seksual laki-laki dapat berimplikasi jauh dalam kehidupan kesehariannya, dimana perempuan senantiasa berhadapan dengan kekerasan, pemaksaan dan penyiksaan baik fisik ataupun psikis (Rahmatiah HL, 2015, h. 35). Oleh karena itulah, kekerasan seksual bukan hanya cerminan dari citra perempuan sebagai objek seks, melainkan sebagai objek kekuasaan laki-laki.

Kekerasan seksual merupakan kekerasan berbasis gender yang terjadinya tidak terlepas dari budaya patriarki. Budaya patriarki merupakan budaya dan ideologi yang berpusat pada laki-laki dan untuk kepentingan laki-laki serta melegitimasi laki-laki sebagai pemegang kekuasaan dan superioritas. Ideologi ini melahirkan sebuah pemikiran bahwa perempuan memiliki kodrat adalah makhluk yang inferior sehingga, menempatkan perempuan dalam posisi yang rentan untuk ditaklukkan dan diperlakukan sesuai keinginan laki-laki, termasuk dengan cara-cara kekerasan. Ideologi patriarki ini mempengaruhi cara berpikir masyarakat, mempengaruhi penafsiran atas teks-teks agama dan juga para pengambil kebijakan. Pengaruh ini melewati kehidupan manusia, baik dalam domain privat (domestik) maupun publik. Ketimpangan yang didasarkan atas ideologi patriarki tersebut berpotensi menciptakan ketidakadilan, subordinasi, streotype dan dominasi atas perempuan serta kekerasan.

Witriyatul Jauhariyah menjelaskan bagaimana budaya patriarki yang masih subur di masyarakat mengajarkan anak laki-laki dengan ego maskulinitas sementara femininitas diabaikan dan dianggap sebagai sifat yang nista. Para orang tua begitu bangga ketika anak lakilaki mereka mempunyai sifat maskulin, macho dan jantan. Sementara mereka diolok-olok jika bersifat feminin. Sebagai contoh, masyarakat seperti membiarkan jika ada laki-laki menggoda dan merayu perempuan yang melintas di jalan, perilaku mereka dianggap sesuatu yang wajar sebab sebagai laki-laki mereka beranggapan harus berani mengahadapi perempuan, laki-laki dianggap sebagai kaum penggoda sementara perempuan adalah objek atau makhluk yang pantas digoda dan tubuh perempuan dijadikan sebab kekerasan itu sendiri (Witriyatul Jauhariyah, 2016). 
Jurnal Ilmu Hukum

FAKULTAS HUKUM UMSU

Lebih lanjut Witriyatul Jauhariyah menjelaskan bahwa melalui budaya patriarki ini, lahir banyak sistem dan kebijakan yang tidak mengakomodir kebutuhan dan kepentingan perempuan. Oleh karena itu, kekerasan terjadi di hampir semua lini kehidupan. Masyarakat kerapkali menimpakan kesalahan kepada perempuan ketika terjadi tindak kekerasan seksual berupa perkosaan. Perempuan yang sudah menjadi korban perkosaan justeru mengalami reviktimisasi karena dianggap sebagai penyebab terjadinya kejadian tersebut. Sebagai contoh, perempuan dipersalahkan sebagai penyebab kekerasan seksual yang dialaminya karena telah memperlihatkan auratnya dengan memakai rok mini atau anggapan bahwa perempuanlah yang menciptakan 'fitnah' dengan menggoda dan memicu hasrat seksual laki-laki karena masih berkeliaran di malam hari (Witriyatul Jauhariyah, 2016).

Asumsi negatif yang dilontarkan masyarakat terhadap korban dan ketidakberpihakannya akan semakin melemahkan kondisi perempuan dan anak korban kekerasan seksual. Penampilan korban dan model pakaiannya kerap kali menjadi alasan pembenar oleh pelaku untuk melakukan kejahatan seksual terhadap perempuan. Perempuan korban kekerasan seksual berkaitan erat dengan gendernya, dimana seluruh perilakunya diharuskan memenuhi harapan dari sistem sosial masyarakat dan budaya. Perempuan dituntut untuk menjadi feminine agar menarik laki-laki, misalnya perempuan memakai rok. Namun pada kondisi perempuan mengalami kekerasan karena dandanannya tersebut, justeru dianggap perempuan nakal karena memakai rok yang dapat menimbulkan birahi laki-laki.

Perlu ditekankan bahwa kekerasan seksual perkosaan terjadi bukan hanya karena pakaian atau penampilan, melainkan kesempatan dan kerentanan. Kerentanan termasuk situasi mental, fokus, waspada dan sadar situasi. Seorang perempuan yang mengenakan pakaian yang sopan, belum tentu dapat menghindari perkosaan, karena dari hasil penelitian diketahui bahwa penampilan bukan merupakan sebab terjadinya perkosaan, karena realitasnya di masyarakat, nenek-nenek dan anak bayi juga menjadi korban perkosaan.

Perempuan yang sama sekali tidak melakukan kejahatan justeru dipersalahkan dan dilecehkan bahkan diperkosa karena pakaian yang dipilihnya. Padahal kekerasan seksual juga ada terjadi terhadap perempuan berjilbab. Pada sisi lain perempuan tanpa jilbab juga tidak selalu menimbulkan perkosaan atau kekerasan seksual dalam bentuk lainnya. Orang yang melihat perempuan tanpa jilbab tidak selalu melakukan pelecehan dan perkosaan. Demikian juga alasan bahwa perkosaan terjadi karena pelaku terpengaruh oleh gambar-gambar porno atau menonton video porno. Tidak semua orang yang melihat gambar atau menonton video porno terlibat dalam aksi kekerasan seksual. Faktor-faktor ini lebih sekedar sebagai pemicu hasrat birahi lakilaki terhadap perempuan.

Mariana Amiruddin mengemukakan pendapatnya bahwa kekerasan seksual senantiasa langgeng terjadi terhadap perempuan karena perempuan dengan tubuhnya yang khas diasumsikan sebagai makhluk sekunder, objek, dapat diperlakukan seenakknya dan dapat menjadi hak milik. Menurut Mariana, dalam berbagai kasus kekerasan terhadap perempuan, dilihat beberapa faktor yang mendasari tindakan tersebut, antara lain: a) Karakteristik fisik dan reproduksinya perempuan memang lebih mudah menjadi korban kekerasan, khususnya 
Jurnal Ilmu Hukum FAKULTAS HUKUM UMSU
Pemenuhan Restitusi Dan...(Atikah Rahmi)

Volume 4 Nomor 2, Juli-Desember 2019, 140-159 DOI: https://doi.org/10.30596/dll.v4i2.3173

kekerasan seksual, seperti perkosaan atau penghamilan paksa; b) Dalam relasinya dengan lakilaki, pemaknaan sosial dari perbedaan biologis tersebut menyebabkan memantapnya mitos, streotipe, aturan, praktik yang merendahkan perempuan dan memudahkan terjadinya kekerasan. c) Dari sisi ekonomi, perempuan dapat dijadikan sarana pengeruk keuntungan, sehingga merebaklah pelacuran, perdagangan perempuan (woman trafficking), atau pornografi; d) Kekerasan terhadap perempuan sekaligus dapat digunakan sebagai sarana terror, penghinaan, atau ajakan perang pada kelompok lain. Kesucian perempuan menurut Mariana dilihat sebagai kehormatan masyarakat, sehingga penghinaan atau perusakan kesucian perempuan akan dipahami sebagai penghinaan terhadap masyarakat (Mariana Amiruddin, 2006, h. 102).

Disi lain Marlina dan Azmiati Zuliah mengemukakan tentang situasi dan kondisi korban yang labil khususnya pada anak, sering menjadi peluang dan kesempatan pelaku tindak pidana, khususnya tindak pidana perdagangan orang dalam melampiaskan niat jahatnya dengan mengiming-imingi korban, akhirnya menjerumuskan korban ke dalam dunia prostitusi, pekerja paksa, meminta-minta di jalanan dan sebagainya. dijelaskan lebih lanjut bahwa pada umumnya, pelaku akan lebih agresif jika korbannya kelihatan lemah (Marlina dan Azmiati Zuliah, 2015, h. 54).

Kekerasan terhadap perempuan dan anak dapat terjadi dimana saja, termasuk di dalam rumah tangga dan bisa berlangsung kapan saja. Pada dasarnya tindak kekerasan ini merupakan tindakan memaksakan kehendak pada perempuan dan anak dengan menggunakan tubuh dan seksualitas perempuan sebagai medium maupun arenanya (Dewi Hairani, 2010, h. 51).

Tindak kekerasan baik dalam bentuk fisik dan maupun psikis mengakibatkan perempuan dan anak menderita. Dampak yang dialami perempuan justeru akan semakin bertambah dengan reaksi masyarakat ketika perempuan jaadi korban. Kondisi korban semakin disudutkan, mereka menjadi terbatasi dalam melakukan peran sosialnya. Dampak kekerasan seksual menimbulkan trauma berkepanjangan terhadap korban, sehingga korban terkadang sangat sulit untuk mengungkapkannya karena akan menambah penderitaan diri korban dan keluarganya. Muncul kekhawatiran keluarga atas asumsi masyarakat terhadap korban yang sebagai seseorang yang tidak bermoral, meskipun prinsipnya mereka mengetahui bahwa tragedi tersebut bukan atas kehendak yang bersangkutan, karena ia hanya korban semata. Tubuh perempuan yang tidak perawan dianggap sebagai barang bekas yang tidak bisa dibeli saat perkawinan. Perempuan akan mengalami perasaan malu yang luar biasa, bahkan korban yang justru disalahkan atas tragedi kekerasan yang dialaminya. Sebaliknya, pelaku malah dianggap wajar melakukan perkosaan.

Beberapa dampak buruk yang dialami korban kekerasan seksual antara lain: (Melalui, http://afaelearning.blogspot.com/2013/10/kesehatan-reproduksi-dalam-dimensi.html)

1) Dampak fisik dan seksual: berupa benturan berakibat memar luar/dalam, cacat fisik permanen, gangguan alat reproduksi, gangguan kehamilan, penyakit menular seksual termasuk HIV/AIDS)

2) Dampak sosial: kesulitan membina relasi baik di lingkungan terdekat ataupun di lingkungan yang lebih luas. Beberapa kasus membuat korban harus membangun 
dunianya sendiri, bersembunyi dan mengisolasi diri dan merasa lebih aman bila berada di dalamnya.

3) Dampak ekonomi: korban harus mengeluarka biaya untuk penyembuhan dirinya baik secara fisik dan mental dari gangguan psikologis yang muncul, bahkan tidak jarang, korban kehilangan pekerjaannya.

4) Dampak psikologis: trauma yang dialami korban, yang mana bentuknya berbeda antara satu korban dengan korban lainnya. Di antara korban ada yang merasa ketakutan, bahkan untuk ketemu dengan orang pun merasa khawatir, mengalami mimpi buruk, emosional, susah tidur dan tidak selera makan, muncul ketidakpercayaan kepada laki-laki, merasa bersalah, merasa malu dan terhina, bahkan trauma berkepanjangan dengan munculnya ingatan akan kejadian yang menimpanya secara tiba-tiba (flesh back).

5) Dampak lanjutan. perilaku anti sosial, perasaan tidak berdaya, harga diri rendah, kecemasan, depresi yang mengakibatkan korban menunjukkan perilaku negatif dengan meminum alkohol, penyalahgunaan obat-obatan terlarang, menjerumuskan diri untuk masuk ke dunia prostitusi, menjadi lesbiyan/gay/transgender, dan bahkan ada yang berupaya untuk bunuh diri.

Kejahatan seksual yang dirasakan korban sangatlah berat dan berakibat pada trauma yang berkepanjangan serta depresi. Johan Runtu mengklasifikasikan dampak kekerasan seksual yang dialami korban pada kondisi fisik, psikologis dan kehidupan pribadi dan bermasyarakat (Johan Runtu, 2012, h. 24). Untuk itu perlu penanganan khusus terhadap anak dan perempuan korban kejahatan seksual, termasuk upaya pemulihan pasca kekerasan yang dialaminya. Cukup banyak penganiayaan atau penyalahgunaan seksual masa kecil yang dilakukan oleh orang-orang terdekat korban, yang berdampak psikologis untuk jangka panjang. Menurut Retno Listryarti, Komisioner Komisi Perlindungan anak Indonesia (KPAI) Bidang Pendidikan, bahwa sekitar $70 \%$ dari seseorang yang mengalami kekerasan seksual saat kecil cenderung menjadi pelaku kekerasan seksual saat dewasa.

Dikdik M. Arief Mansur mengemukakan kekecewaannya tentang korban kejahatan yang pada dasarnya merupakan pihak yang paling menderita dalam suatu tindak pidana, justru tidak memperoleh perlindungan sebanyak yang diberikan oleh undang-undang kepada pelaku kejahatan. Akibatnya, pada saat pelaku kejahatan telah dijatuhi sanksi pidana oleh pengadilan, kondisi korban kejahatan seperti tidak diperdulikan sama sekali. Padalah, masalah keadilan dan penghormatan hak asasi manusia tidak hanya berlaku terhadap pelaku kejahatan saja, tapi juga korban kejahatan. Kedudukan korban sebagai subjek hukum memiliki kedudukan sederajat di depan hukum (equality before the law) (Dikdik M. Arief Mansur, 2008, h. 24).

\section{Restitusi dan kompensasi sebagai bentuk perlindungan bagi perempuan dan anak korban kekerasan seksual}

Pengertian korban sebagaimana dikemukakan Arif Gosita "Mereka yang menderita jasmaniah dan rohaniah sebagai akibat tindakan orang lain yang mencari pemenuhan diri sendiri atau orang lain yang bertentangan dengan kepentingan dan hak asasi yang menderita" (Arif Gosita dalam Bambang Waluyo, 2011, h. 9). Pengertian yang dikemukakan oleh Arif Gosita 
Jurnal Ilmu Hukum

FAKULTAS HUKUM UMSU

sejalan dengan apa yang dicantumkan dalam Undang-Undang Momor 13 Tahun 2006 tentang Perlindungan Saksi dan Korban, yaitu "Seseorang yang mengalami penderitaan fisik, mental dan/atau kerugian ekonomi yang diakibatkan oleh suatu tindak pidana".

Beranjak dari pengertian tentang korban, maka korban merupakan pihak yang dirugikan dan menderita akibat perbuatan seseorang dan oleh karenanya perlindungan terhadap korban kejahatan seksual, merupakan hal yang mutlak untuk diberikan karena pelanggaran terhadap hak-haknya. Perlindungan sebagaimana dimaksudkan dalam Pasal 1 angka 1 Undang-Undang Momor 13 Tahun 2006 tentang Perlindungan Saksi dan Korban "Upaya pemenuhan hak dan pemberian bantuan untuk memberikan rasa aman kepada korban yang wajib dilaksanakan oleh Lembaga Perlindungan Saksi dan Korban (LPSK) atau lembaga lainnya sesuai dengan ketentuan. Perlindungan ini diberikan dalam semua tahapan proses peradilan pidana”.

Upaya perlindungan hukum terhadap perempuan dan anak korban pemerkosaan baik anak maupun dewasa, merupakan perjuangan atas hak-hak mereka. Hak sebagai anak dan hak sebagai perempuan merupakan bagian dari hak asasi manusia yang wajib dijamin, dilindungi dan dipenuhi. Secara teoritis, bentuk perlindungan terhadap korban kejahatan dapat diberikan dalam berbagai cara, tergantung pada penderitaan/kerugian yang diderita oleh korban. Dikdik M Arief Mansur, Elisatris (2007, h. 162-163) menyebutkan bahwa penerapan hak-hak korban kejahatan merupakan akibat dari terlanggarnya hak asasi yang bersangkutan.

Menurut beliau, dasar dari perlindungan korban kejahatan dapat dilihat dari beberapa teori berikut: (Dikdik M Arief Mansur, Elisatris, 2007, h. 162-163)

1) Teori Utilitas yang minitikberatkan pada kemanfaatan yang terbesar bagi jumlah yang terbesar. Konsep perlindungan korban diterapkan sepanjang memberikan kemanfaatan yang lebih dibandingkan tidak diterapkan konsepnya.

2) Teori tanggungjawab yang mengarah bahwa pada hakikatnya setiap orang harus mempertanggungjawabkan perbuatan hukum yang dilakukannya termasuk tindak pidana yang mengakibatkan penderitaan bagi korban.

3) Teori ganti kerugian yaitu sebagai wujud tanggungjawab karena kesalahan pelaku, maka dibebani kewajiban memberikan ganti rugi kepada korban atau ahli warisnya.

Lebih lanjut Dikdik yang mengambil pendapat Arif Gosita mengemukakan beberapa asas hukum yang diperlukan dalam konsep perlindungan korban, yaitu (Dikdik, 2007, h. 163):

1) Asas manfaat, maksudnya bahwa perlindungan korban tidak saja ditujukan untuk kemanfaatan korban, tetapi termasuk kemanfaatan bagi masyarakat luas, khususnya dalam mengurangi angka tindak pidana dan menciptakan ketertiban masyarakat

2) Asas Keadilan, artinya penerapan asas keadilan dalam upaya melindungi korban kejahatan tidak bersifat mutlak karena hal ini dibatasi oleh rasa keadilan yang harus diberikan kepada pelaku kejahatan

3) Asas Keseimbangan, maksudnya adalah kepastian dan perlindungan hukum diberikan untuk kepentingan manusia dan juga untuk memulihkan keseimbangan tatanan masyarakat yanag terganggu menuju pada keadaan yang seperti semula. Asas keseimbangan memperoleh tempat yang penting dalam upaya pemulihan korban. 
Jurnal Ilmu Hukum

FAKULTAS HUKUM UMSU

4) Asas Kepastian Hukum memberikan dasar pijakan hukuman yang kuat bagi aparat penegak hukum pada saat melaksanakan tugasnya dalam upaya memberikan perlindungan hukum pada korban kejahatan.

Asas-asas perlindungan korban juga diatur dalam Pasal 3 Undang-Undang Nomor 13 Tahun 2006 tentang Perlindungan Saksi dan Korban yaitu asas penghargaan atas harkat dan martabat manusia, rasa aman, keadilan, tidak diskriminatif dan kepastian hukum. Uriannya yaitu;

1) Asas penghargaan atas harkat dan martabat manusia merupakan asas dalam pemenuhan hak dan pemberian bantuan yang melihat manusia khususnya saksi dan/atau korban sebagai makhluk ciptaan Allah yang harus dihargai dan dilindungi.

2) Asas rasa aman yaitu asas dalam pemenuhan hak dan pemberian bantuan kepada saksi dan/atau korban, berguna untuk menciptakan kondisi dalam suasana tenteram baik lahiriah dan batiniah, baik secara fisik dan maupun psikis.

3) Asas keadilan adalah asas dalam pemenuhan hak dan pemberian hukum kepada saksi dan/atau korban sesuai dengan hak-haknya, secara proposionalitas, procedural, sesuai dengan kewajibannya memberikan kesaksian dalam setiap tahap peradilan.

4) Asas tidak diskriminatif adalah asas dalam pemenuhan hak dan pemberian bantuan yang memandang setiap saksi dan/atau korban memperoleh pengakuan yang dalam keadan sama, harus diterapkan secara sama di depan hukum, tanpa membedakan tingkat ekonomi, golongan, ras, agama, suku bangsa.

5) Asas kepastian hukum adalah asas dalam pemenuhan hak dan pemberian bantuan di Negara hukum yang mengutamakan landasan peraturan perundang-undangan, kepatutan dan keadilan dalam setiap kebijakan penyelenggara Negara.

Siswanto Sunarso menjelaskan bahwa perlindungan terhadap saksi dan korban merupakan hak yang didasarkan atas keputusan yang dikeluarkan oleh Lembaga Perlindungan Saksi dan Korban, diberikan sejak tahap penyelidikan dan berakhir sesuai dengan ketentuan yang diatur undang-undang. Keputusan yang ditetapkan oleh LPSK menyangkut pemberian hak restitusi dan kompensasi yang diajukan kepada hakim melalui perantara LPSK (Siswanto Sunarso, 2015, h. 260).

Bentuk perlindungan korban dapat dilakukan dengan reparasi (pemulihan kondisi korban), konpensasi (ganti kerugian yang diberikan oleh negara karena pelaku tidak mampu memberikan ganti kerugian sepenuhnya yang menjadi tanggung jawabnya), restitusi (ganti kerugian yang diberikan kepada korban atau keluarganya oleh pelaku atau pihak ketiga, dapat berupa pengembalian harta milik, pembayaran ganti kerugian untuk kehilangan atau penderitaan, atau penggantian biaya untuk tindakan tertentu) dan rehabilitasi (upaya pemulihan korban) (Melalui, http://opsikpkkudus.blogspot.com/).

Dikdik M. Arief Mansur berpendapat bahwa terjadi pemahaman yang salah selama ini yang menganggap bahwa hukuman yang diberikan kepada pelaku telah memberikan rasa keadilan bagi korban. Akibatnya, ketika korban kemudian menuntut adanya pemberian ganti kerugian, maka hal tersebut dianggap merupakan tindakan yang berlebihan. Sebenarnya hampir tidak ada korelasi yang signifikan antara hukuman yang diberikan dengan perlindungan terhadap korban, karena hukuman tersebut belum mampu mengembalikan hak-hak korban yang 
Jurnal Ilmu Hukum

FAKULTAS HUKUM UMSU
Pemenuhan Restitusi Dan...(Atikah Rahmi)

Volume 4 Nomor 2, Juli-Desember 2019, 140-159

DOI: https://doi.org/10.30596/dll.v4i2.3173

telah dilanggar dan tidak mampu memberikan pemulihan pada korban (Dikdik M. Arief Mansur, 2008, h. 24).

Hak yang sangat penting sebagai korban yang menderita secara fisik juga yaitu mendapatkan restitusi dan kompensasi atas akibat penderitaan yang dialaminya. Sebagaimana dikemukakan oleh Maya Indah bahwa perlindungan korban khususnya hak korban untuk mendapatkan ganti rugi merupakan bagian integral dari hak asasi di bidang kesejahteraan dan jaminan sosial (social security) (Maya Indah 2014, h. 133).

Basic Principles of Justice for Victim of Crime and Abuse of Power memberikan penjelasan yang berikaitan dengan restitusi yaitu: "Offenders or third paries responsible for their behaviour should, where appropriate, make fair restitution to victims, their families or dependants. Such restitution should include the return of property or payment for the harm or loss suffered, reimbursement of expenses incurred as a result of the victimization, the provision of services and the restoration of rights (Dikdik M. Arief Mansur, Elisatris Gultom: 2007, h. 166).

Sebagai korban yang menderita secara fisik berhak untuk mendapatkan restitusi dan maupun kompensasi akibat penderitaan yang dialaminya. Hal ini tertuang dalam Deklarasi Prinsip-prinsip Kekuasaan (Resolusi Majelis Umum PBB N0. 40/34, 29 November 1985) yang isinya mengatur:

1) Para korban berhak untuk mendapatkan penggantian segala kerugian yang mereka derita

2) Mereka harus diinformasikan tentang hak-hak mereka untuk mendapatkan ganti rugi

3) Para pelaku atau pihak ketiga harus memberikan restitusi yang adil bagi para korban dan keluarga.

4) Bilamana kompensasi tidak sepenuhnya didapatkan dari pelaku atas sumber-sumber lainnya Negara harus berusaha menyediakan kompensasi keuangan

5) Para korban harus mendapat dukungan dan bantuan material, pengobatan, psikologis dan sosial yang diperlukan. (Rahmatiah: 2015, h. 47).

Pemenuhan ganti kerugian berupa restitusi dan kompensasi kepada korban diharapkan mampu memberikan nuansa perlindungan pada korban karena dengan demikian, korban dan atau keluarganya dapat melakukan proses pemulihan dari rasa tidak nyaman akibat kekerasan yang dialaminya. Ganti rugi atau restitusi yang dimaksudkan adalah ganti rugi atas hilangnya materi, penghasilan, penderitaan, biaya untuk tindakan perawatan medis dan/atau psikologis dan/atau kerugian lain yang diderita korban sebagai akibat tindakan kekerasan yang dialami korban.

Pengertian restitusi dan kompensasi menurut Dikdik adalah merupakan istilah yang dalam penggunaannya sering dipertukarkan, namun perbedaan antara kedua istilah tersebut bahwa kompensasi lebih bersifat keperdataan, muncul dari permintaan korban dan dipenuhi oleh masyarakat atau Negara. Sedangkan restitusi lebih bersifat pidana yang timbul dari putusan pengadilan pidana dan dibayar oleh terpidana (Dikdik, 2007, h. 167).

Rahmatiah HL menekankan bahwa pengertian kompensasi sebagai bentuk santunan yang dapat dilihat dari aspek kemanusiaan dan hak-hak asasi. Adanya gagasan mewujudkan 
kesejahteraan sosial masyarakat dengan berlandaskan pada komitmen kontrak sosial dan solidaritas sosial menjadi masyarakat dan Negara bertanggungjawab dan berkewajiban secara moral untuk melindungi warganya (Rahmatiah HL, 2015, h. 47).

Pengaturan mengenai ganti rugi dalam sistem hukum di Indonesia dapat dilihat dari beberapa perundangan sebagai berikut:

\section{Pasal 14c Kitab Undang-Undang Hukum Pidana (KUHP)}

Pasal 14c KUHP menyebutkan;

Apabila hakim menjatuhkan pidana percobaan, maka disamping penetapan syarat umum, bahwa terhukum tidak akan melakukan tindak pidana, dapat pula ditetapkan syarat khusus, bahwa terhukum dalam waktu tertentu yang lebih pendek dari masa percobaan, harus mengganti seluruh atau sebagian kerugian yang ditimbulkan oleh tindak pidana itu.

Namun, KUHP belum merumuskan ketentuan yang dapat memberikan perlindungan terhadap korban. KUHP juga tidak merumuskan jenis pidana restitusi (ganti rugi) bagi korban dan atau keluarganya. KUHP masih berorientasi terhadap pelaku, sehingga korban cenderung diabaikan. Menurut Bardanawawi dalam (Maya Indah, 2014, h. 141), Pasal 14C KUHP ini pada dasarnya tidak bersifat pidana dan hanya sekedar pengganti untuk menghindari atau tidak menjalani perkara pidana. Oleh karenanya pasal tersebut hanya melandaskan pada ide dasar pemidanaan yang berorientasi pada kepentingan pelaku dan bukan pada kepentingan korban.

\section{Pasal 98 ayat (1) sampai Pasal 101 Kitab Undang-Undang Hukum Aacar Pidana (KUHAP)}

Pasal 98 sampai dengan Pasal 101 KUHAP berkaitan dengan hak korban dalam menuntut ganti kerugian dengan cara menggabungkan perkara gugatan ganti rugi pada perkara pidana. Marlina dan Azmiati Zuliahberpendapat bahwa penggabungan perkara ganti rugi dimaksudkan agar perkara gugatan tersebut pada waktu yang sama diperiksa serta diputus sekaligus dengan perkara pidana yang bersangkutan (Marlina, Azmiati Zuliah, 2015, h. 62).

Lebih lanjut Marlina dan Azmiati menjelaskan bahwa kerugian bagi orang lain yang dimaksud termasuk kerugian pihak korban, yaitu perbuatan terdakwa yang merupakan tindak pidana yang menimbulkan kerugian bagi orang tersebut. Kata "dapat" berarti bahwa hakim dalam menyidangkan kasus tersebut dapat menolak atau menerima permohonan dalam hal penggabungan perkara ganti rugi dengan perkara pidananya. Dengan demikian dibuka peluang bagi hakim untuk mengambil kebijakan apakah dapat diajukan secara perdata atau digabungkan sehingga membuka kesempatan bagi hakim untuk menolak penggabungan perkara yang diajukan. Pada prinsipnya, penggabungan perkara pidana dan perdata sejalan dengan asas peradilan yang sederhana, cepat dan biaya ringan. Untuk itu, sebaiknya bagi korban untuk menuntut ganti rugi sekalian tanpa harus menunggu selesainya perkara pidana tersebut. Namun pada Pasal 99 ayat (1) KUHAP dibatasi bahwa ganti rugi yang diajukan terbatas pada hukuman penggantian biaya yang nyata telah dikeluarkan oleh pihak yang dirugikan, sehingga tuntutan lain berupa kerugian immaterial tidak dapat diterima dan harus diajukan sebagai perkara perdata biasa. 
DE LEGA LATA

Jurnal Ilmu Hukum

FAKULTAS HUKUM UMSU
Pemenuhan Restitusi Dan...(Atikah Rahmi)

Volume 4 Nomor 2, Juli-Desember 2019, 140-159

DOI: https://doi.org/10.30596/dll.v4i2.3173

\section{Undang-Undang Nomor 26 Tahun 2000 tentang Pengadilan Hak Asasi Manusia}

Pasal 35 UU Pengadilan HAM menyebutkan "Setiap korban pelanggaran hak asasi manusia yang berat dan atau ahli warisnya dapat memperoleh konpensasi, restitusi dan rehabilitasi". Ayat selanjutnya menyebutkan bahwa "Konpensasi, restitusi dan rehabilitasi sebagaimana dimaksud dalam ayat (1) dicantumkan dalam amar putusan Pengadilan HAM". Lebih lanjut dalam ayat (3) disebutkan bahwa ketentuan mengenai konpensasi, restitusi dan rehabilitasi diatur lebih lanjut dalam peraturan pemerintah.

Pengertian tentang restitusi, kompensasi dan rehabilitasi dijabarkan dalam penjelasan Pasal 35 UU Pengadilan HAM dan lebih lanjut diatur dalam PP N0. 3 Tahun 2002 tentang Kompensasi, Rehabilitasi dan Restitusi bagi Korban Pelanggaran HAM yang Berat. Kompensasi diartikan sebagai ganti kerugian yang diberikan oleh Negara, karena pelaku tidak mampu memberikan ganti kerugian sepenuhnya yang menjadi tanggungjawabnya. Sedangkan restitusi yaitu ganti kerugian yang diberikan kepada korban atau keluarganya oleh pelaku atau pihak ketiga. Namun Undang-Undang Nomor 26 Tahun 2006 tentang Pengadilan Hak Asasi Manusia ini hanya membatasi pada pelanggaran HAM berat seperti kejahatan genosida dan kejahatan kemanusian saja.

Menurut Dikdik M Arief dan Elisatris, pengertian kompensasi dalam Penjelasan Pasal 35 Undang-Undang Nomor 26 Tahun 2006 tentang Pengadilan Hak Asasi Manusia memiliki kemiripan dengan pengertian dalam Basic Principles of Justice for Victim of Crime and Abuse of Power yang menyatakan: "Iwhen compensation is not fully abailable from the offender or the other sources, states shoul endeavour to provide financial compensation" (Dikdik M Arief, Elisatris, 2007, h. 167).

\section{Undang-Undang No. 15 Tahun 2003 Tentang Penetapan Perppu No. 1 Tahun 2002 Tentang Pemberantasan Tindak Pidana Terorisme}

Pasal 36 Undang-Undang Pemberantasan Tindak Pidana Terorisme menyebutkan:

a) Setiap korban atau ahli warisnya akibat tindak pidana terorisme berhak mendapat kompensasi atau restitusi.

b) Kompensasi sebagaimana dimaksud dalam ayat 1 pembiayaannya dibebankan kepada Negara yang dilaksankan oleh Pemerintah

c) Restitusi sebagaimana dimaksud dalam ayat 1 merupakan ganti kerugian yang diberikan oleh pelaku kepada korban atau ahli warisnya

d) Kompensasi dan/atau restitusi tersebut diberikan dan dicantumkan sekaligus dalam amar putusan pengadilan.

Undang-Undang Nomor 1 Tahun 2002 tentang Pemberantasan Tindak Pidana Teorisme juga mengatur tentang mekanisme pengajuan restitusi dan kompensasi. Restitusi diajukan kepada pelaku atau pihak ketiga berdasarkan amar putusan, sementara kompensasi dilakukan oleh korban atau kuasanya kepada menteri keuangan berdasarkan amar putusan Pengadilan Negeri. 
Jurnal Ilmu Hukum

FAKULTAS HUKUM UMSU

\section{Undang-Undang Nomor 31 Tahun 2014 Tentang Perubahan atas Undang-Undang Nomor 13 Tahun 2006 Tentang Perlindungan Saksi dan Korban}

Undang-Undang Nomor 31 Tahun 2014 Tentang Perubahan atas Undang-Undang Nomor 13 Tahun 2006 Tentang Perlindungan Saksi dan Korban mengatur mengenai hak korban untuk mendapatkan ganti rugi berupa restitusi. Restitusi tersebut berbentuk penggantian biaya perawatan medis dan psikologis. Hak restitusi diatur dalam Undang-Undang Nomor 31 Tahun 2014 Tentang Perubahan atas Undang-Undang Nomor 13 Tahun 2006 Tentang Perlindungan Saksi dan Korban yang mekanismenya dikuasakan kepada Lembaga Perlindungan Saksi dan Korban (LPSK). Pasal 7 Undang-Undang Nomor 31 Tahun 2014 Tentang Perubahan atas Undang-Undang Nomor 13 Tahun 2006 Tentang Perlindungan Saksi dan Korban menyebutkan korban melalui LPSK berhak mengajukan ke pengadilan berupa:

a) Hak atas kompensasi dalam kasus pelanggaran hak asasi manusia yang berat

b) Hak atas restitusi atau ganti kerugian yang menjadi tanggung jawab pelaku

c) Keputusan mengenai kompensai dan restitusi diberikan oleh pengadilan

d) Ketentuan lebih lanjut mengenai pemberian kompensasi dan restitusi diatur dalam Peraturan Pemerintah

Undang-Undang Nomor 31 Tahun 2014 Tentang Perubahan atas Undang-Undang Nomor 13 Tahun 2006 Tentang Perlindungan Saksi dan Korban meskipun telah merekomendasi hakhak korban diwakilkan melalui lembaga LPSK tersebut, namun dalam prakteknya belum berjalan efektif karena korban masih saja sebagai saksi korban dalam peradilan dan hak-haknya diwakili oleh polisi dan jaksa.

\section{Undang-Undang Nomor 21 Tahun 2007 Tentang Tindak Pidana Perdagangan Orang}

Undang-Undang Nomor 21 Tahun 2007 tentang Pemberantasan Tindak Pidana Perdagangan Orang mengatur mengenai restitusi dalam Pasal 1 ayat 13 dan Pasal 48 hingga Pasal 50. Pemberantasan Tindak Pidana Perdagangan Orang sedikit berbeda dengan KUHAP tentang ganti kerugian ini, karena dalam KUHAP hanya dapat dimintakan gugatan untuk penggantian kerugian materil saja, sementara Pemberantasan Tindak Pidana Perdagangan Orang juga mencakup kerugian yang immaterial.

Kerugian materiil yang dimaksud meliputi kerugian akibat kehilangan harga milik, biaya transportasi dasar, biaya pengacara, atau biaya lain yang berhubungan dengan proses hukum atau kehilangan penghasilan yang dijanjikan pelaku. Kerugian immaterial meliputi kerugian akibat proses penyiksaan dan eksploitasi yang dialami korban, serta stigmatisasi dan trauma psikologis yang dialami korban.

Pelaku yang tidak dapat memenuhi tanggungjawabnya akan diambil alih oleh negara. Dalam hal ini muncul konsep tanggungjawab negara terhadap korban untuk dapat mengembalikan keadaan korban dengan memberikan ganti rugi dan pemulihan atas hak-hak korban yang hilang seperti hak atas pendidikan, kesehatan, pekerjaan, pemulihan psikologis dan pelayanan sosial. Ketentuan tersebut sejalan dengan apa yang disebutkan dalam Deklarasi Prinsip-Prinsp Dasar Keadilan Bagi Korban Kejahatan Dan Penyalahgunaan Kekuasaan huruf 
Jurnal Ilmu Hukum

FAKULTAS HUKUM UMSU

a butir 12 yang menetapkan apabila imbalan (restitusi) tidak sepenuhnya tersedia dari orang yang bersalah atau sumber-sumber lain. Negara harus memberikan imbalan keuangan kepada:

a) Para korban yang menderita luka jasmani berat atau kemerosotan fisik atau mental sebagai akibat kejahatan yang serius

b) Keluarga, terutama tanggungan dari orang-orang yang meninggal atau menjadi lumpuh secara fisik atau mental sebagai akibat kejahatan tersebut.

Undang-Undang Nomor 35 Tahun 2014 Tentang Perubahan Atas Undang-Undang Nomor 23 Tahun 2002 Tentang Perlindungan Anak

Pasal 64 ayat 3 Undang-Undang Nomor 35 Tahun 2014 tentang Perubahan atas UndangUndang Nomor 23 Tahun 2002 Tentang Perlindungan Anak juga telah menjamin hak-hak anak sebagai korban untuk mendapatkan rehabilitasi baik dalam lembaga maupun luar lembaga, upaya perlindungan dan pemberitaan identitas melalui media massa untuk menghindari labelisasi, pemberian jaminan keselamatan bagi saksi korban dan saksi ahli baik fisik, mental maupun sosial dan pemberian aksebelitas untuk mendapatkan informasi mengenai perkembangan perkara.

\section{Peraturan Pemerintah Nomor 43 Tahun 2017 tentang Pelaksanaan Restitusi Bagi Anak yang Menjadi Korban Tindak Pidana}

Pemerintah juga telah menerbitkan Peraturan Pemerintah Nomor 43 Tahun 2017 tentang Pelaksanaan Restitusi Bagi Anak yang Menjadi Korban Tindak Pidana. Peraturan ini merupakan pelaksanaan dari Pasal 71D Undang-Undang Nomor 35 Tahun 2014 tentang Perubahan atas Undang-Undang Nomor 23 Tahun 2002 tentang Perlindungan Anak. Harapannya dengan terbitnya Peraturan Pemerintah Nomor 43 Tahun 2017 tentang Pelaksanaan Restitusi Bagi Anak yang Menjadi Korban Tindak Pidana maka anak yang menjadi korban tindak pidana bisa mendapatkan restitusi (ganti rugi).

Peraturan Pemerintah Nomor 43 Tahun 2017 tentang Pelaksanaan Restitusi Bagi Anak yang Menjadi Korban Tindak Pidana ini lebih rinci memuat ketentuan tentang anak yang dapat mengajukan permohonan restitusi yaitu; setiap anak yang menjadi korban tindak pidana yang meliputi: a. anak yang berhadapan dengan hukum, b. anak yang dieksploitasi secara ekonomi dan/atau seksual, c. anak yang menjadi korban pornografi d. anak korban penculikan, penjualan dan/atau perdagangan, e. anak korban fisik dan psikis, g. anak korban kejahatan seksual. Restitusi sebagaimana yang dimaksudkan dalam Pasal 3 Peraturan Pemerintah Nomor 43 Tahun 2017 tentang Pelaksanaan Restitusi Bagi Anak yang Menjadi Korban Tindak Pidana menjelaskan terkait dengan ganti kerugian atas kehilangan kekayaan, ganti kerugian atas penderitaan sebagai akibat tindak pidana dan penggantian biaya perawatan medis dan/atau psikologis. Pasal 5 ayat 2 Peraturan Pemerintah Nomor 43 Tahun 2017 tentang Pelaksanaan Restitusi Bagi Anak yang Menjadi Korban Tindak Pidana ini mengatur bahwa permohonan restitusi dapat dilakukan sebelum putusan pengadilan melalui tahap penyelidikan dan/atau penuntutan. Restitusi juga dapat diajukan melalui LPSK. 
Jurnal Ilmu Hukum FAKULTAS HUKUM UMSU
Pemenuhan Restitusi Dan...(Atikah Rahmi)

Volume 4 Nomor 2, Juli-Desember 2019, 140-159

DOI: https://doi.org/10.30596/dll.v4i2.3173

\section{KESIMPULAN DAN SARAN \\ Kesimpulan}

Kekerasan seksual merupakan kejahatan yang menodai harkat dan martabat seseorang yang akibatnya akan menimbulkan penderitaan dan depresi. Korban yang hakekatnya sudah menderita secara fisik dan psikis tentunya berhak untuk mendapatkan perlindungan. Bentuk perlindungan dapat berupa restitusi, kompensasi dan pemulihan. Penderitaan yang dialami oleh korban dan keluarganya sangat mendalam dan tidak cukup hanya dengan menghukum pelaku saja, karena hukuman yang diberikan kepada pelaku masih menyisakan masalah, yaitu hak-hak keperdataan korban yang tentu mengalami kerugian materiil dan immateriil, rohani dan jasmani meliputi kerugian spiritual, mental, jiwa, psikis, fisik, sosial, ekonomi, dan masa depan yang tidak ternilai. Korban dan keluarganya membutuhkan perlindungan berupa pemenuhan restitusi dan kompensasi untuk dapat memenuhi kebutuhan korban yang telah dirampas oleh pelaku.

\section{Saran}

Diharapkan agar Penerapan konsep hak restitusi dan kompensasi diterapkan secara maksimal dalam sistem peradilan pidana di Indonesia. Perlu sosialisasi kepada aparat penegak hukum agar memahami dan memperjuangkan hak-hak korban untuk mendapatkan restitusi dan kompensasi. Selain itu, juga diperlukan suatu aturan yang jelas dalam melakukan penghitungan kerugian immaterial yang dialami korban serta merubah konsep ganti kerugian yang mengandalkan kepada pelaku menjadi tanggungjawab yang diambil alih oleh Negara dengan tetap membebankannya kepada pelaku melalui sanksi pidana denda dan perampasan hak milik. 
Jurnal Ilmu Hukum

FAKULTAS HUKUM UMSU
Pemenuhan Restitusi Dan...(Atikah Rahmi)

Volume 4 Nomor 2, Juli-Desember 2019, 140-159

DOI: https://doi.org/10.30596/dll.v4i2.3173

\section{DAFTAR PUSTAKA}

Amiruddin, Mariana (2016). Perkosaan Bukan Soal Seks. Tapi Kekuasaan. Jurnal Perempuan edisi 71; 2006.

Dikdik, Mansur., M. Arief., Gultom, Elisatris. (2008). Urgensi Perlindungan Korban Kejahatan Antara Norma dan Realita. PT. Raja Grafindo: Jakarta.

Gosita, Arif. (1993). Masalah Korban Kejahatan. Jakarta: Akademika Pressindo.

Gultom, Maidin. (2010). Perlindungan Hukum Terhadap Anak dalam Sistem Peradilan Pidana Anak di Indonesia. Bandung: Refika Aditama.

Hamzah, Abu 'Abdul Lathif al-Ghamidi. (Ed). (2010). Stop KDRT (Kekerasan Dalam Rumah Tangga) Membuang Prahara Kekerasan di Rumah dengan Kembali Kepada Tuntunan Islam, diterjemahkan oleh Ahmad Noviadi. (2010). Jakarta: Pustaka Imam Syafi'i.

HL, Rahmatiah. (2015). Perlindungan Hukum Terhadap Korban Tindak Pidana Perkosaan (Studi Kasus Pengadilan Negeri Sungguminasa). al Daulah. Volume 4/No 1/ Juni/ 2015.

Indah, Maya S. (2014). Perlindungan Korban Suatu Perspektif Viktimologi dan Kriminologi Jakarta: Kencana Prenadamedia.

Jauhariyah, Witriyatul. (2017). Akar Kekerasan Seksual Terhadap Perempuan. Diakses pada tanggal 6 Juni 2017 melalui http://www.jurnalperempuan.org/blog-muda1/-akarkekerasan-seksual-terhadap-perempuan.

Kusuma, Mulyana W. (1988). Kejahatan Dan Penyimpangan. Jakarta: Yayasan LBH.

Marlina, Zuliah. Azmiati. (2015). Hak Restitusi Terhadap Korban Tindak Pidana Perdaganan Orang. Bandung: Refika Aditama.

Moeljatno. (2009). Asas-asas Hukum Pidana. Jakarta: Renaka Cipta.

Nasriana. (2012). Perlindungan Hukum Pidana Bagi Anak Di Indonesia. Jakarta: Raja Wali Pers.

Noviana, Ivo. (2015). Kekerasan Seksual Terhadap Anak: Dampak dan Penanganannya. Diakses pada tanggal 5 Juli 2017 melalui https://media.neliti.com/media/publications/52819-ID-kekerasan-seksual-terhadapanak-dampak-d.pdf2015.

Prodjodikoro, Wirjono. (2010). Tindak-Tindak Pidana Tertentu Di Indonesia. Bandung: PT Refika Aditama.

Rahmi, Atikah. (2018). Urgensi Perlindungan Bagi Korban Kekerasan Seksual dalam Sistem Peradilan Pidana Terpadu Berkeadilan Gender. Jurnal Mercatoria. Volume 11/Nol/Juni/2018.

Saragih, Dina (Ed). (2010). Pesada Menulis Di Usia 20 Tahun Melayani dan Menguatkan Dengan Semboyan Sinceritas et Simplicititas. Sumatera Utara: Perkumpulan Sada Ahmo (Pesada). 
Savitri, Niken. (2008). HAM Perempuan Kritik Teori Hukum Feminis Terhadap KUHP. Refika Aditama: Bandung.

Soemitro, Irma., \& Setyowati. (2012). Aspek Hukum Perlindungan Anak. Jakarta: PT. Rajawali Grasindo Persada.

Sofian, Ahmadi. (2012). Perlindungan Anak Di Indonesia Dilema dan Solusinya. PT. Sofmedia: Medan.

Sudarto. (1986). Hukum dan Hukum Pidana. Bandung: Alumni.

Sunarso, Siswanto. (2015). Viktimologi Dalam Sistem Peradilan Pidana. Jakarta: Sinar Grafika.

Supriyanta. (2009). KUHAP dan Sistem Peradilan Pidana Terpadu. Wacana Hukum. Vol VII. April 2009.

Wahid, Abdul Muhammad Irfan. (2001). Perlindungan Terhadap Korban Kekerasan Seksual Advokasi atas Hak Asasi Perempuan. Refika Aditama: Bandung.

Waluyo, Bambang. (2011). Viktimologi Peerlindungan Korban dan Saksi. Jakaarta: Sinar Grafika. 